\title{
PENINGKATAN KEMAMPUAN PENGEMBANGAN DIRI MELALUI TEKNIK SHAPING PADA SISWA TUNAGRAHITA RINGAN
}

\author{
Elsy Dwiandriani \\ SLB Negeri Sungailiat Bangka Belitung \\ email: elsidwiandriani15@gmail.com
}

\begin{abstract}
ABSTRAK
Tulisan yang berbasis Penelitian Tindakan Kelas (PTK, Classroom Action Research) yang dilaksanakan di Sekolah Luar Biasa (SLB) Negeri Sungailiat Bangka Belitung ini bertujuan meningkatkan kemampuan pengembangan diri dalam menyetrika pakaian bagi siswa tunagrahita, khususnya tunagrahita ringan. Sebagai kolaborator adalah teman sejawat. Subjek penelitian ini adalah siswa tunagrahita ringan kelas 5 sebanyak 5 orang. PTK ini dilakukan dalam 2 siklus, masing-masing siklus terdiri atas 4 kali pertemuan. Data program khusus pengembangan diri diperoleh melalui observasi, tes, dan catatan lapangan. Setelah diberikan tindakan melalui teknik shaping pada siklus I, nilai siswa mengalami peningkatan, meskipun belum maksimal. Maka, dilakukanlah siklus II. Hasilnya, teknik shaping dapat meningkatkan kemampuan pengembangan diri secara optimal dalam menyetrika pakaian. Kriteria keberhasilan ditetapkan berdasarkan ketercapaian minimal pada kategori baik. Dapat disimpulkan bahwa teknik shaping dapat meningkatkan kemampuan pengembangan diri menyetrika pakaian pada siswa tunagrahita ringan.
\end{abstract}

Kata kunci: pengembangan diri, teknik shaping, tunagrahita ringan.

\section{PENDAHULUAN}

Pendidikan, seperti sudah dipahami bersama, adalah usaha sadar dan terencana untuk mewujudkan suasana belajar dan proses pembelajaran agar peserta didik secara aktif mengembangkan potensi dirinya untuk memiliki kekuatan spiritual, keagamaan, pengendalian diri, kepribadian, kecerdasan, akhlak mulia, dan keterampilan yang diperlukan untuk dirinya, keluarga, masyarakat, bangsa, dan negara. Pendidikan juga merupakan usaha yang dilakukan untuk mengembangkan sumber daya manusia melalui kegiatan pembelajaran. Pendidikan pada dasarnya bertujuan untuk mengembangkan kemampuan peserta didik secara optimal, baik aspek pengetahuan, sikap, keterampilan, maupun sosial. 
Penyelenggaraan pendidikan anak tunagrahita berorientasi pada kemampuan, kebutuhan, dan permasalahan yang dihadapi oleh mereka. Layanan pendidikan sesungguhnya lebih banyak ditekankan pada layanan individual, mengingat adanya sifat heterogenitas yang dialami anak tunagrahita. Undangundang Republik Indonesia Nomor 20 Tahun 2003 tentang Sistem Pendidikan Nasional Bab IV tentang Hak dan Kewajiban Warga Negara, Orang Tua, Masyarakat, dan Pemerintah, Pasal 5 ayat 2 mengemukakan bahwa warga negara yang memiliki kelainan fisik, emosional, mental, intelektual, dan/atau sosial berhak memperoleh pendidikan khusus.

Anak tunagrahita merupakan salah satu dari anak berkebutuhan khusus yang merupakan bagian dari masyarakat Indonesia yang mempunyai hak, kewajiban, dan peran yang sama dengan anggota masyarakat yang lain agar dapat berperan aktif, tentu saja, sesuai kemampuan yang dimiliki. Anak tunagrahita yang secara signifikan memiliki kecerdasan di bawah rata-rata memiliki hak dan kebutuhan yang sama untuk berkembang atau mengaktualisasikan potensinya, sehingga mereka dapat mandiri. Dengan tingkat inteligensi yang di bawah ratarata, anak tunagrahita memiliki hambatan, sehingga perlu diberikan pelayanan pendidikan yang berbeda dari anak seusia pada umumnya. Anak tunagrahita mempunyai kemampuan, masalah, dan kebutuhan yang sangat heterogen. Heterogenitas ini akan membawa konsekuensi bagi tindakan-tindakan guru di dalam kegiatan pembelajaran. Kegiatan pembelajaran untuk mereka tidak lagi didasarkan semata-mata pada kecerdasan intelektual yang direduksi dalam bentuk angka kecerdasan (intelligentsia question) yang sifatnya abstrak dan umum, melainkan pada pertimbangan kemampuan, masalah, dan kebutuhan nyata dari kondisi yang dihadapi anak tunagrahita. Secara substantif pendidikan bagi anak tunagrahita bertujuan untuk mengembangkan potensi dirinya agar dapat hidup mandiri di tengah masyarakat.

Hambatan yang dijumpai anak tunagrahita adalah dalam perilaku adaptif. Untuk itu, diperlukan program khusus yaitu bina diri atau sekarang disebut program pengembangan diri (Bina Diri, BD). Program khusus BD merupakan hal 
yang teramat penting bagi anak tunagrahita. BD sangat penting bagi siswa tunagrahita karena diarahkan pada kemandirian aktivitas yang berhubungan dengan kegiatan dan kehidupan sehari-hari, sehingga tidak akan membebani orang lain. Program Khusus BD adalah program yang merupakan pembelajaran yang diberikan kepada siswa berkebutuhan khusus dengan hambatan intelektual (tunagrahita) dalam melakukan kegiatan sehari-hari, yang bertujuan agar siswa dapat mandiri dan tidak bergantung kepada orang lain.

Siswa tunagrahita dengan rendahnya tingkat kecerdasan yang dimilikinya mengakibatkan mereka tidak mampu mengurus diri mereka yang berkaitan dengan aktivitas hidup sehari-hari. Aktivitas hidup sehari-hari ini meliputi kegiatan mandi, makan, minum, berpakaian, menggunakan toilet, menggosok gigi, dan kegiatan merawat diri yang lain. Dengan ketidakmampuan anak tunagrahita dalam mengurus dan merawat diri, tak jarang ditemui kondisi mereka yang terkesan jorok dan bau, sehingga masyarakat masih banyak yang belum bisa menerima kehadiran mereka sebagaimana mestinya. Menurut Astati (2013: 8) tujuan program khusus pengembangan diri adalah untuk mengembangkan keterampilan dasar dalam memelihara dan memenuhi kebutuhan peserta didik tunagrahita, sehingga dapat hidup mandiri dengan tidak/kurang bergantung kepada orang lain, bahkan mempunyai tanggung jawab sesuai kemampuannya sebagai makhluk individu maupun makhluk sosial. Sedangkan tujuan khusus pengembangan diri peserta didik tunagrahita adalah menumbuhkan dan meningkatkan kemampuan peserta didik tunagrahita dalam tatalaksana pribadi (mengurus diri, menolong diri sendiri, merawat diri, dan sebagainya), kemampuan dalam berkomunkasi, sehingga dapat mengomunikasikan keberadaan dirinya, dan kemampuan dalam bersosialisasi.

Dalam kurikulum Sekolah Luar Biasa, pelajaran Pengembangan Diri terdapat dalam mata pelajaran Program Khusus (Progsus). Program Khusus untuk anak tunagrahita dinamakan Pengembangan Diri. Dengan bimbingan khusus yang diberikan, siswa tunagrahita ringan dapat mengembangkan kemampuan yang masih mereka miliki, sehingga kebergantungan anak tunagrahita ringan dapat 
dikurangi atau dihilangkan. Ruang lingkup Program Khusus Pengembangan Diri bagi peserta didik tunagrahita mencakup beberapa aspek, yaitu keterampilan merawat diri, keterampilan mengurus diri, keterampilan menolong diri, keterampilan berkomunikasi, keterampilan bersosialisasi, keterampilan hidup, dan keterampilan menggunakan waktu luang (Kementerian Pendidikan dan Kebudayaan, 2014). Metode yang diarahkan dalam pengembangan diri peserta didik tunagrahita adalah pembelajaran terpadu, mengembangkan keterampilan hidup, menggunakan berbagai media/sumber belajar yang relevan, berorientasi pada prinsip perkembangan dan kemampuan.

Dari beberapa ruang lingkup pengembangan diri yang telah disebutkan di atas, keterampilan pengembangan diri yang dimaksud dalam penelitian ini adalah keterampilan dalam menolong diri sendiri. Keterampilan dalam menolong diri sendiri adalah pelajaran yang berkaitan dengan kegiatan yang biasa dilakukan untuk mengatasi berbagai masalah dalam kehidupan sehari-hari. Aktivitas yang dimaksud adalah berbagai pekerjaan sehari-hari di rumah, seperti memasak sederhana, memakai pakaian/baju, memakai sepatu, memakai kaos kaki, menyapu, mencuci pakaian, mencuci piring, menyetrika pakaian, dan seterusnya.

Program khusus pengembangan diri memiliki peran sentral dalam mengantarkan anak tunagrahita dalam melakukan kegiatan untuk dirinya sendiri. Melalui pembelajaran itu anak diarahkan untuk mengaktualisasikan dan mengembangkan kemampuan dalam melakukan aktivitas hidup sehari-hari, sehingga untuk mewujudkan kebutuhan dirinya sendiri mereka tidak membebani orang lain.

Salah satu kompetensi dalam kurikulum program khusus pengembangan diri adalah anak dapat menyetrika pakaian. Menyetrika pakaian kedengarannya sangat mudah dan sederhana. Bagi anak normal, kemampuan ini akan mudah dicapai dengan melihat apa yang diajarkan oleh orang lain. Tetapi, bila itu diaplikasikan kepada anak tunagrahita, kemungkinan besar mereka tidak dapat atau kurang bisa melakukan sendiri tanpa diajarkan atau dilatih terlebih dahulu. Apalagi, jika ditambah dengan kurangnya pemahaman orang tua dan masyarakat 
tentang keberadaan anak tunagrahita. Orang tua kebanyakan menganggap ketidakmampuan yang dimiliki anak tunagrahita untuk melakukan sesuatu pekerjaan adalah sesuatu yang sederhana, sehingga mereka cenderung dimanjakan. Akibatnya banyak anak tunagrahita tidak mengoptimalkan potensi yang dimilikinya. Kondisi ini semakin menyebabkan ketidakberdayaan anak. Apalagi adanya anggapan masyarakat bahwa anak tunagrahita tidak mampu berbuat terhadap tuntutan hidup layaknya anak normal, sehingga mereka dijauhkan dan disisihkan dari kehidupan normal/biasa.

Belum selarasnya kebutuhan pelaksanaan pengembangan diri dengan kondisi sekolah dan kemampuan guru, membuat program pengembangan diri belum dapat diimplementasikan secara optimal. Sekalipun secara teori dan cara pelaksanaannya telah dipahami oleh para guru secara rinci, namun program pembelajaran pengembangan diri belum menunjukkan kemajuan yang berarti dalam keberhasilannya mengembangkan diri anak tunagrahita.

Kondisi kelas V SLB Negeri Sungailiat Bangka menunjukkan kemampuan pengembangan diri dalam aspek menyetrika pakaian sangatlah rendah. Hal itu juga didukung oleh pengakuan dari orang tua anak. Menurut pengakuan mereka, dalam menyetrika pakaian, anak belum pernah melakukannya, karena dianggap berbahaya, anak lamban dalam mengerjakannya, kurang rapi, dan kesibukan yang harus dilakukan orang tua. Maka, orang tua selalu mengerjakannya sendiri. Buktibukti juga menunjukkan ketika program khusus pengembangan diri menyetrika pakaian, guru memberi tugas kepada anak-anak, ternyata anak kebingungan. Atas dasar itulah peneliti ingin meningkatkan kemampuan pengembangan diri anak tunagrahita ringan dalam topik menyetrika pakaian.

Dalam pembelajaran menyetrika pakaian sendiri, guru sudah membelajarkan berbagai cara di antaranya secara langsung menugasi anak untuk menyiapkan pakaian yang akan disetrika. Ternyata anak bingung dan belum mengenal peralatan yang akan digunakan. Jangankan untuk menyetrika pakaian, cara menggunakannya pun anak belum paham sama sekali. Melihat kenyataan itulah, peneliti melakukan pembelajaran pengembangan diri dalam kemampuan 
menyetrika pakaian. Ketika pembelajaran berlangsung, semestinya guru menggunakan teknik pembelajaran yang tepat agar mudah memberikan pemahaman kepada anak tunagrahita. Selain itu, guru harus menggunakan media belajar secara langsung, sehingga anak secara langsung akan memperagakan apa yang ingin dicapai dalam materi pembelajaran, sehingga anak dapat melakukannya secara mandiri di manapun berada. Jika kemampuan pengembangan diri dalam menyetrika pakaian ini dilakukan secara kontinu atau terus-menerus, di kemudian hari kemampuan menyetrika pakaian ini dapat dijadikan pekerjaan bagi anak tunagrahita untuk mendapatkan penghasilan.

Ada banyak teknik yang digunakan dalam meningkatkan kemampuan pengembangan diri siswa tunagrahita ringan. Teknik-teknik tersebut misalnya stimulus fading, forward and backward chaining, rewarding or positive reinforcement, modeling and shaping (Kaur \& Kumar, 2015). Dalam pembelajaran pengembangan diri menyetrika pakaian, penyampaian materi pembelajaran diberikan mengacu pada karakteristik siswa tunagrahita ringan, yaitu diberikan dengan membagi beberapa tahapan kegiatan menjadi beberapa langkah kecil agar siswa tunagrahita ringan dapat dengan mudah mengikutinya. Dengan rendahnya tingkat kecerdasan yang dimiliki anak, siswa tunagrahita ringan kurang mampu menerima beberapa perintah secara bersamaan. Dari beberapa teknik tersebut peneliti menggunakan teknik shaping dalam meningkatkan keterampilan pengembangan diri pada siswa tunagrahita ringan.

Teknik shaping merupakan salah satu teknik yang digunakan oleh guru dalam pembelajaran pengembangan diri kepada siswa tunagrahita ringan, untuk mengurangi perilakunya yang selalu bergantung kepada orang lain di sekitarnya, yakni dalam hal mengurus dirinya yang bersifat pribadi. Menurut Dewi (2016) teknik shaping adalah suatu teknik yang dilakukan untuk mencapai tujuan akhir atau perilaku yang diharapkan dengan cara memecah tahapan yang dipelajari menjadi langkah-langkah yang lebih rinci, disertai dengan pemberian penguatan pada setiap tahapan yang berhasil dikuasai oleh siswa. Sedangkan Faz (2015) 
menyatakan bahwa shaping merupakan sebuah prosedur yang dilakukan untuk membentuk suatu pola perilaku yang belum pernah dimunculkan.

Dapat disimpulkan bahwa teknik shaping adalah prosedur yang digunakan untuk mencapai perilaku sasaran, yang dilakukan dengan membagi setiap tahapan kegiatan dimulai dari tahap yang mudah ke tahap yang lebih sulit, dengan adanya pemberian penguatan untuk setiap perilaku yang muncul. Menurut Gutbrod (2014) penerapan teknik shaping dilakukan dengan beberapa tahapan, yaitu menentukan perilaku akhir yang diinginkan atau target behavior, menentukan tingkah laku awal yang dimiliki oleh anak atau baseline, menentukan langkahlangkah pembentukan perilaku atau task analysis, mulai memperbaiki perilaku. Dengan demikian, teknik shaping adalah teknik yang dilakukan oleh guru melalui tahapan dari yang mudah ke yang sulit, sehingga membentuk perilaku yang belum pernah dimunculkan.

\section{METODE}

Penelitian tindakan kelas (PTK, classroom action research) dilakukan memperbaiki masalah pembelajaran di kelas. Dalam penelitian ini peneliti sekaligus guru kelas terlibat langsung, mulai dari perencanaan, tindakan, pengamatan, dan refleksi. PTK ini dilaksanakan dalam dua siklus. Setiap siklus dilaksanakan 4 kali pertemuan yang terdiri atas 4 tahap, yaitu perencanaan, tindakan, observasi, dan refleksi.

PTK ini dilaksanakan di SLB Negeri Sungailiat Bangka-Belitung, SLB yang di dalamnya ada beberapa spesialisasi, yaitu tunanetra, tunarungu, tunagrahita, tunadaksa, dan autis. Subjek penelitian ini adalah siswa tunagrahita ringan kelas 5 yang berjumlah 5 orang, yaitu AZ, DA, LU, MZ, dan RD. Objek penelitian ini adalah kemampuan pengembangan diri siswa tunagrahita ringan dalam menyetrika pakaian. Metode pengumpulan data menggunakan observasi, studi dokumentasi, dan tes. Observasi dilakukan berpedoman pada catatan lapangan dan instrumen observasi. Studi dokumentasi berupa foto atau video yang dilakukan setiap pembelajaran pengembangan diri menyetrika pakaian. 
Sedangkan tes yang dilakukan berupa tes lisan dan tes perbuatan. Tes lisan dilakukan dengan tanya jawab untuk mengukur tingkat pengetahuan siswa terhadap kegiatan menyetrika pakaian dan perbuatan digunakan untuk mengukur bagaimana kemampuan siswa dalam menyetrika pakaian. Peneliti berkolaborasi dengan teman sejawat. Penelitian ini dilakukan pada jam pelajaran Program Khusus (Pengembangan Diri) selama 4 jam pelajaran dalam 1 minggunya.

\section{HASIL DAN PEMBAHASAN}

Proses pembelajaran pengembangan diri dalam menyetrika pakaian menggunakan teknik shaping sebagai berikut. Untuk kegiatan awal pembelajaran, peneliti melakukan kegiatan apersepsi, yakni bertanya kepada siswa: 1) apakah hari ini pakaiannya disetrika; 2) kalau iya, siapakah yang menyetrikanya. Kemudian, peneliti mengajak siswa berdoa sebelum belajar dan menjelaskan tujuan serta manfaat dari menyetrika pakaian. Pada kegiatan inti proses pembelajaran dilakukan dengan peneliti terlebih dahulu menjelaskan peralatan atau perlengkapan yang digunakan dalam menyetrika pakaian secara rinci dan beberapa kali diulang dalam menjelaskannya. Peneliti juga melakukan tanya jawab dengan siswa tentang apa saja langkah-langkah yang dilakukan ketika mau menyetrika pakaian. Selanjutnya, pada tahap praktek menyetrika pakaian, peneliti terlebih dahulu mencontohkan dengan benar kepada siswa tunagarahita ringan bagaimana langkah-langkah menyetrika pakaian mulai dari langkah awal sampai dengan langkah akhir dalam gerakan lambat. Hal ini dikarenakan lambatnya daya tangkap pada siswa tunagrahita. Setelah peneliti mencontohkan satu langkah kegiatan menyetrika pakaian, siswa selanjutnya diminta untuk mengulang kembali langkah tersebut. Jika siswa belum berhasil melakukannya dengan benar atau belum sesuai dengan yang telah dicontohkan sebelumnya, peneliti kemudian mengulang kembali mencontohkan langkah tersebut sampai siswa berhasil melakukannya dengan benar. Jika siswa telah berhasil melakukan satu langkah yang telah dicontohkan maka peneliti memberikan reward kepada siswa berupa pujian, mengacungkan jempol, dan melakukan tos dengan siswa tersebut. Anak 
tunagrahita harus sering diberi motivasi berupa pujian, sehingga mereka tidak merasa bosan untuk melakukan aktivitas-aktivitas yang harus mereka lakukan.

Berdasarkan analisis data, diagram menunjukkan bahwa teknik shaping dapat meningkatkan kemampuan menyetrika pakaian pada siswa tunagrahita ringan. Pada siklus I, nilai yang diperoleh oleh siswa pada aspek menyebutkan peralatan yang digunakan untuk menyetrika 60, pada aspek menunjukkan peralatan yang digunakan untuk menyetrika pakaian, siswa memperoleh nilai 65 , pada aspek menyebutkan langkah-langkah untuk menyetrika pakaian, siswa memperoleh nilai 50, dan pada aspek mendemonstrasikan langkah-langkah kegiatan menyetrika pakaian, siswa memperoleh nilai 55. Gambaran peningkatan kemampuan menyetrika pakaian pada siswa tunagrahita ringan untuk siklus I sebagai berikut.

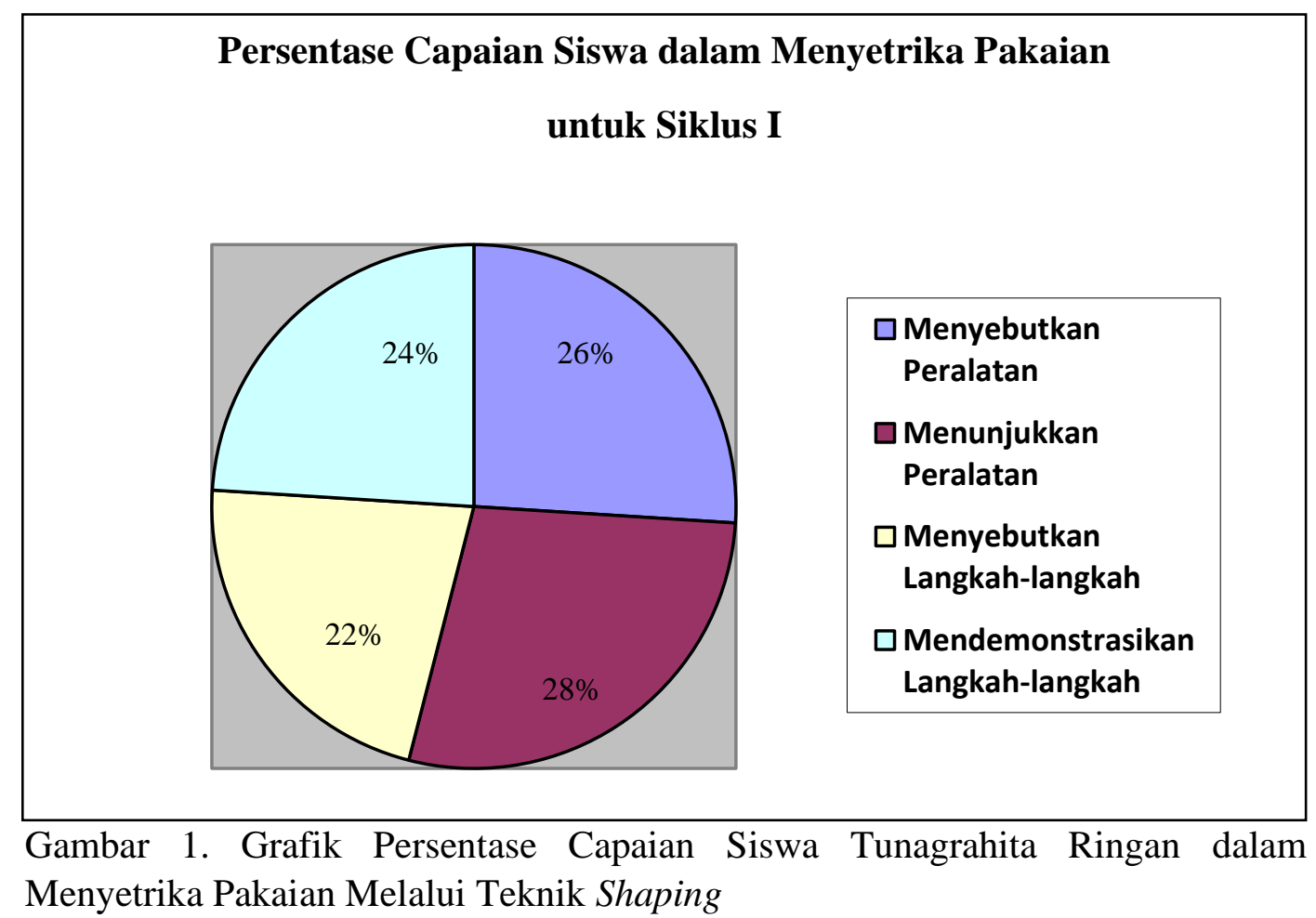

Grafik di atas menunjukkan bahwa nilai siswa mengalami peningkatan setelah diberikan tindakan melalui teknik shaping. Meskipun nilai yang diperoleh 
belum maksimal. Oleh karena itu, peneliti dan kolaborator sepakat untuk melanjutkan ke siklus II. Untuk siklus II, nilai yang diperoleh siswa dalam menyetrika pakaian aspek menyebutkan peralatan yang digunakan dalam menyetrika, siswa memperoleh nilai 80 , pada aspek menunjukkan peralatan yang digunakan dalam menyetrika, siswa memperoleh nilai 85, dalam aspek menyebutkan langkah-langkah dalam menyetrika pakaian, siswa memperoleh nilai 80, dan dalam aspek mendemonstrasikan langkah-langkah kegiatan menyetrika pakaian, siswa memperoleh nilai 88. Gambaran peningkatan kemampuan menyetrika pakaian pada siswa tunagrahita ringan untuk siklus II sebagai berikut.

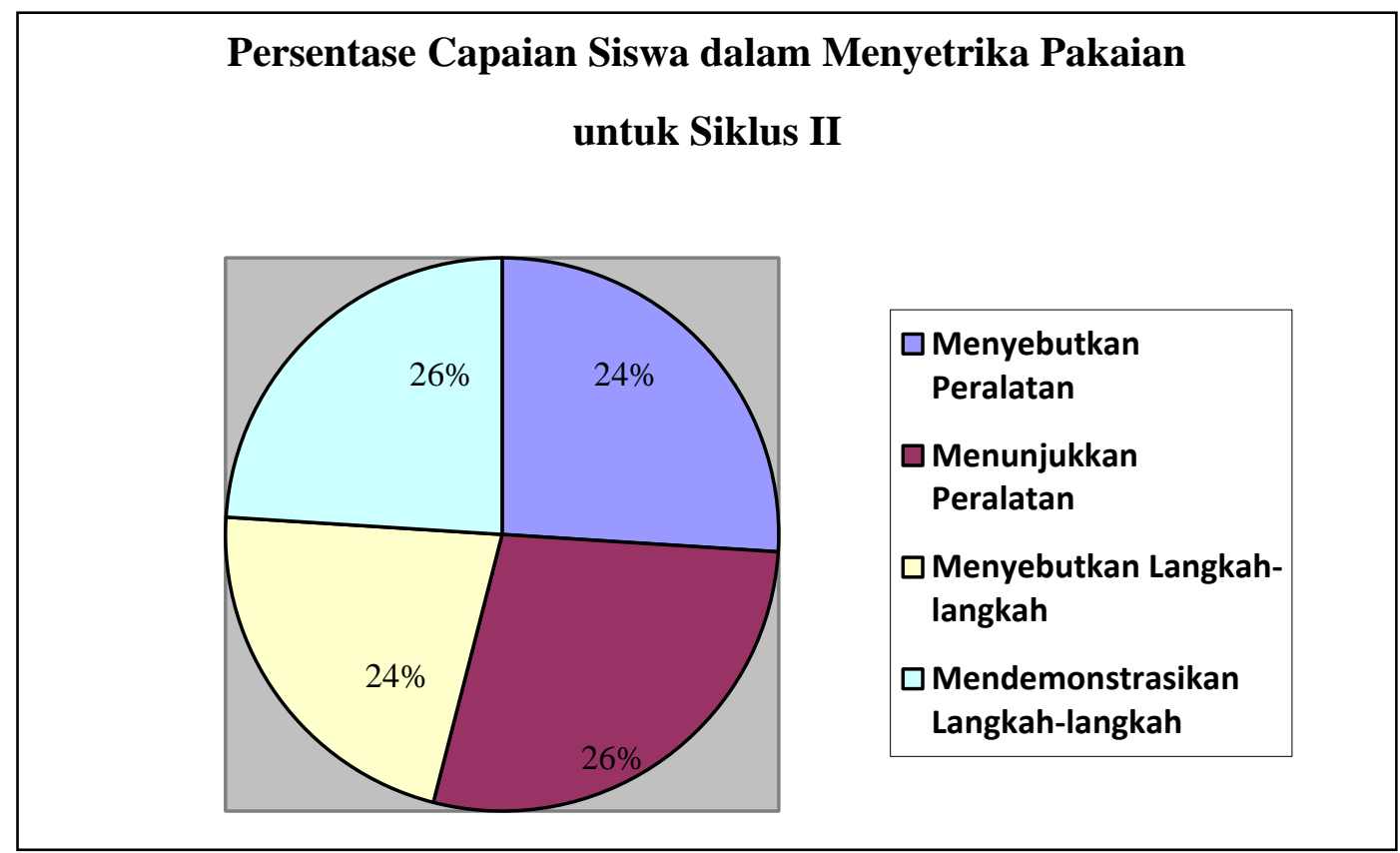

Gambar 2. Grafik Persentase Capaian Siswa Tunagrahita Ringan dalam Menyetrika Pakaian Melalui Teknik Shaping

Dari hasil yang diperoleh tersebut dapat diketahui nilai siswa mengalami peningkatan yang cukup signifikan, meski siswa masih memerlukan bimbingan dari peneliti. Berdasarkan perolehan nilai yang didapatkan dari siklus I dan II 
dapat dikatakan bahwa penggunaan teknik shaping dalam meningkatkan kemampuan pengembangan diri menyetrika pakaian pada siswa tunagrahita ringan. Berdasarkan hasil refleksi yang dilakukan oleh peneliti dan kolaborator, penelitian ini dapat dihentikan pada akhir siklus II.

Setelah dilakukan tindakan dengan menggunakan teknik shaping untuk meningkatkan kemampuan pengembangan diri menyetrika pakaian pada siswa tunagrahita ringan, siswa terlihat dapat mengikuti proses pembelajaran dengan cukup baik. Siswa juga dapat melakukan langkah-langkah kegiatan menyetrika pakaian yang dicontohkan oleh peneliti. Pakaian yang dipilihkan untuk pembelajaran pertama bagi siswa yang belum pernah sama sekali menyetrika pakaian, sebaiknya yang tanpa kancing terlebih dahulu. Hal ini sejalan dengan langkah-langkah perbaikan tingkah laku menggunakan teknik shaping seperti yang dikemukakan oleh Munawaroh (2019), bahwa setiap langkah kegiatan dimulai dengan langkah-langkah yang kecil. Jika langkah yang sudah dicapai itu hilang, maka pengulangan harus dimulai dari langkah awal.

Dengan menggunakan teknik shaping ini kemampuan menyetrika pakaian pada siswa tunagrahita mengalami peningkatan. Hal ini sejalan dengan hasil penelitian yang dilakukan Anggraini, Ivo \& Marlina (2018) bahwa teknik shaping merupakan teknik yang dapat digunakan untuk membelajarkan berbagai keterampilan, termasuk keterampilan pengembangan diri dalam menyetrika pakaian.

Pada siklus I kemampuan siswa dalam menyetrika pakaian mengalami peningkatan setelah diberikan tindakan menggunakan teknik shaping, walaupun masih belum optimal. Hal itu dikarenakan masih terdapat beberapa kekurangan, misalnya siswa dalam menyetrika pakaian terkadang masih sering lupa tentang langkah-langkahnya. Demikian pula, hasil setrikaannya pun masih belum rapi. Setelah pemberian tindakan masuk pada siklus II, nilai siswa mengalami peningkatan yang signifikan. Meskipun siswa masih memerlukan bimbingan dari peneliti. Keterampilan pengembangan diri, khususnya menyetrika pakaian, sangat 
penting diberikan kepada siswa tunagrahita ringan agar siswa mampu berpenampilan rapi dan bersih dengan mandiri tanpa bantuan orang lain.

\section{SIMPULAN}

Program pengembangan diri khusus menyetrika pakaian ini peneliti melakukan tindakan dengan melakukan tanya jawab dengan siswa tentang peralatan yang digunakan dalam menyetrika pakaian dan manfaat serta tujuan menyetrika pakaian. Ternyata pada awalnya anak-anak bingung, belum mengenal peralatan yang akan digunakan, bahkan belum paham sama sekali cara penggunaannya. Berangkat dari itu, pembelajaran pengembangan diri dalam kemampuan menyetrika pakaian dilakukan dengan PTK.

Proses pembelajaran yang dilakukan (action) adalah peneliti menjelaskan peralatan atau perlengkapan yang digunakan dalam menyetrika pakaian secara rinci, dan diulangi beberapa kali. Pada tahap praktek menyetrika pakaian, peneliti terlebih dahulu mencontohkan langkah-langkah menyetrika pakaian. Kemudian siswa diminta mengulangi kegiatan tadi. Ketika siswa berhasil melakukan suatu langkah yang dicontohkan, peneliti memberikan pujian dan tepuk tangan kepada siswa. Apabila siswa tidak bisa melakukan suatu kegiatan yang dilakukan peneliti, peneliti mencontohkan kembali kegiatan tersebut sampai siswa berhasil melakukannya.

Setelah dilakukan tindakan dengan menggunakan teknik shaping pada siklus I, kemampuan siswa mengalami peningkatan, meskipun masih belum optimal. Setelah pemberian tindakan dilakukan pada siklus II, nilai siswa mengalami peningkatan yang signifikan, walaupun siswa masih tetap memerlukan bimbingan peneliti. 


\section{Daftar Pustaka}

Anggraini, Ivo \& Marlina. 2018. Peningkatan Keterampilan Bina Diri Melalui Teknik Shaping pada Siswa Tunagrahita Ringan. Jurnal Penelitian Pendidikan Kebutuhan Khusus, 2622-5077.

Astati. 2013. Bina Diri Untuk Anak Tunagrahita. Bandung: CV Catur Karya Mandiri.

Basuni, M. 2012. Pembelajaran Bina Diri Pada Anak Tunagrahitan Ringan. Jurnal Pendidikan Khusus, IX, 12-22.

Depdikbud. 2016. Program Khusus Pengembangan Diri. Jakarta: Depdikbud.

Dewi, Shofa Yunne Nisrina. 2016. Efektivitas Penggunaan Strategi Shaping Terhadap Pembelajaran Keterampilan Mengukur Tekanan Udara Ban Pada Anak Tunagrahita Kategori Ringan Kelas VIII Di Sekolah Luar Biasa Negeri 1 Sleman. Universitas Negeri Yogyakarta.

Kementrian Pendidikan dan Kebudayaan. 2014. Pedoman Pengembangan Diri Untuk Peserta Didik Tunagrahita. Jakarta: Direktorat Jenderal Pendidikan Dasar.

Munawaroh, Titin. 2019. Peningkatan Kemampuan Pengembangan Diri Dalam Memakai Baju Melalui Teknik Shaping Pada Siswa Tunagrahita Ringan Kelas IV SLB Korpri Kauman. Jurnal Pena SD.

Saptunar. 2012. Meningkatkan Keterampilan Menyetrika Pakaian Anak Tunagrahita Sedang. Jurnal Ilmiah Pendidikan Khusus, 1 (1), 102-112. 